GINZBURG, Carlo.

\title{
Medo, reverência, terror. Quatros ensaios de iconografia política
}

Tradução de Federico Carotti, Júlio Castañon Guimarães

e Joana Angélica d'Avila Melo. São Paulo: Companhia das Letras, 2014. 200p.

\author{
Elson de Assis Rabelo \\ Colegiado de Artes Visuais \\ Universidade Federal do Vale do São Francisco \\ Av. Antonio Carlos Magalhães, 510, Juazeiro, BA, 48.902-300, Brasil \\ elson_rabelo@hotmail.com
}

Já faz algum tempo que a dimensão visual da história e da vida em sociedade tem chamado a atenção do principal nome do campo conhecido como micro-história, seja na Itália ou fora dela. Depois de seus estudos mais importantes nesse campo, o autor passou a explorar o gênero do ensaio, com a verve da polêmica e da erudição, como se vê nas obras Relações de força, Olhos de madeira, O fio e os rastros, nas quais Carlo Ginzburg tem apresentado sucessivamente não apenas seu farto conhecimento sobre longos períodos da história do Ocidente, particularmente da Europa, mas tem posto essa erudição em função de problemas históricos instigantes, a partir das possibilidades dadas pelo método indiciário que ele sistematizara em texto hoje clássico.

O ponto de partida que reúne os quatros capítulos do seu mais recente livro, Medo, reverência, terror, originalmente publicados como quatro ensaios independentes, é a temática mais ou menos comum que

\footnotetext{
Recebido 20 de fevereiro de 2014 | Aprovado 14 de dezembro de 2014 http://dx.doi.org/10.1590/0104-87752015000100016 Varia Historia, Belo Horizonte, vol. 31, n. 55, p. 307-311, jan/abr 2015
} 
lhes abrange e que Ginzburg filia ao conceito de Pathosformeln. Lançado pelo historiador da arte alemão Aby Warburg, mestre de uma geração e conhecida referência do autor italiano, o conceito designa as fórmulas históricas de representação das emoções na arte, vazadas na gestualidade corporal ou na expressividade facial dos sujeitos. Mas, desta vez, trata-se de uma releitura, considerando-se que Ginzburg, em Mitos, Emblemas, Sinais, já mapeara o conceito sobre a obra de Warburg.

Como "instrumento analítico", as Pathosformeln constituem uma noção que "ilumina as raízes antigas de imagens modernas e a maneira como tais raízes foram reelaboradas" (p.12), especialmente sob o signo da ambivalência entre emoções contraditórias. As Pathosformeln informariam a criação visual, mesmo que o próprio artista eventualmente não saiba de onde vêm essas formas que ele emprega. Ao acentuar a tensão entre morfologia e história, que também havia sido abordada antes, Ginzburg, enquanto historiador, testa o conceito em favor da condição histórica das obras de arte, de sua criação e recepção, com ênfase na questão do político e dos temas das três emoções correlatas (medo, reverência, terror) que, embora distintas, teriam se reforçado e sustentado a dominação, a contestação e a memória do poder.

Ricos em imagens, os capítulos têm o mérito de não reduzi-las ao uso ilustrativo, mas convoca-as para a narrativa, chamando o leitor para que veja os indícios privilegiados na abordagem. No entanto, esse exercício chega a ser um tanto exaustivo, dado o volume de vestígios e informações levantados, que pedem, e permitem, mais análise das imagens em si mesmas. Inclusive, no primeiro capítulo, o privilégio não é dado à imagem e sua constituição: o próprio Ginzburg diz que trata, antes, de um caso de Logosformel ("fórmula de ideias"), pois a abordagem sobre os frontispícios de duas edições do Leviatã, de Hobbes, cede espaço à discussão dos conceitos do medo e da reverência, onde são exploradas as possíveis conotações religiosas da construção filosófica do pensador inglês sobre o Estado, contrariando a tradição que o considera já secularizado, e secularizador, da política.

No segundo capítulo, uma das mais famosas pinturas do período revolucionário francês, o Marat em seu último suspiro, de Jacques-Louis 
David, é confrontada com outras obras de seu tempo e com as formas capturadas indiretamente da religião e que teriam favorecido o surgimento do "culto" a esse personagem político. O terceiro capítulo indaga detalhes do cartaz que trazia o rosto do marechal-de-campo inglês Lord Kitchener, no começo do século XX, que veio a inspirar não apenas o cartaz estadunidense de recrutamento para a guerra com o rosto do Tio Sam, como também vários produtos similares da propaganda política que tiveram por função intimar o espectador. Segundo o historiador, a língua "demótica" da propaganda atualizou um motivo clássico da pintura - aquele do olhar vigilante e do dedo apontado que parecem saltar da tela rumo ao espectador por força da expressão pictórica.

O quarto capítulo, em que Ginzburg mais uma vez visita a obra de Pablo Picasso, depois do ensaio anteriormente publicado sobre Demoiselles d’Avignon, é, sem dúvida, o mais denso, e o que mais chama a atenção dos historiadores interessados nas circunstâncias sociais de elaboração de uma obra de arte. Após nova digressão pelos temas clássicos da pintura das paixões encarnadas nos corpos, temas que de algum modo chegaram a Picasso, Ginzburg olha para a iconosfera e para os impressos que envolviam o pintor, antes e no momento da produção de Guernica, em 1937: a arquitetura, os objetos escultóricos, a imprensa, os textos surrealistas. E o cotejamento com os esboços fotografados do mural ampliam ainda mais esse espectro documental, e colocam a possibilidade de análise das operações de escolha e exclusão do artista, repercutidas na obra acabada e no tecido histórico para o qual ela virá à luz e do qual fará parte.

Pode-se dizer que os ensaios de Ginzburg têm a ver com um momento em que a historiografia tem se preocupado com aquilo que foi chamado por vários nomes, como cultura visual, modos de ver, com a visualização, enfim, do passado - e que não é preocupação exclusiva dos historiadores que privilegiam a abordagem de documentos visuais, mas um ângulo estratégico de questionamento dos vestígios que pode interessar seja aos historiadores da arte, seja aos da mídia, ou aos da política. E isso é indicativo de uma atenção ética, pontuada pelo autor logo no primeiro capítulo, ao assédio exercido atualmente pelas imagens, que, 
por sua ubiquidade, tornaram-se cada vez mais indissociáveis das nossas práticas de conhecimento, de produção cultural e de inserção na esfera do político. Embora o autor defina critérios próprios de análise e chegue às suas conclusões em função de problemas específicos, é inegável a constatação de que seus textos engrossam a fileira de uma historiografia que tem relacionado o político e a dimensão visual, exemplificada no capítulo sobre poder e protesto do livro de Peter Burke, Testemunha Ocular, ou no outro livro deste sobre Luís XIV, e nas diferentes tradições de estudos que têm relacionado a arte às suas demais implicações na sociedade, e daí podem se incluir, dentre outros, os nomes de importantes historiadores, como o próprio Warburg e seu círculo de Hamburgo e Londres, Pierre Francastel, Svetlana Alpers, Michael Baxandall, Louis Marin e Georges Didi-Huberman, embora Ginzburg se afaste deliberadamente de algumas perspectivas deste último.

Resta que, em que pese a defesa, por Ginzburg, de um método por excelência conjectural, nem sempre ficam claros os trânsitos de perdas e acréscimos das Pathosformeln, o que demandaria estudos de mais fôlego do que os ensaios podem comportar. Mas isso em si é revelador de que o historiador italiano não toma o conceito de Warburg como cartilha mecânica, mas como provocação para que se investiguem questões particulares com rigor de método para tratar os artefatos trabalhados como documentos, como ele demonstra em relação ao circuito social de produção, circulação e, eventualmente, consumo de algumas obras.

Além disso, lembramos que certas vertentes da historiografia brasileira, por vezes genericamente chamada de "história cultural", acostumaram-se a trabalhar com as emoções e sensibilidades, nem sempre com chaves de leituras como a do medo, mas, em todo caso, com pouca articulação com a questão do político, e pouca exploração da dimensão visual, salvo algumas exceções. Mas se existe nesse tipo de abordagem o risco de só ver os vestígios históricos das emoções naqueles produtos que foram nomeados como o sendo o "sorriso da sociedade" (como a arte, a literatura ou mesmo a publicidade), seria possível pensar na existência, entre os grupos sociais sem escrita e sem o mercado institucionalizado de arte, de formas históricas recorrentes, e que sofrem 
reinterpretações, na expressão e na representação das emoções? Seus vínculos, cotidianos, insuspeitos, com a política, não constituiriam matéria de interesse para o historiador, sobretudo em espaços, como os que há e houve no Brasil, nos quais a política, seus ritos e seu espetáculo foram durante muito tempo expressos, veiculados e vividos em termos orais, gestuais, costumeiros, cerimoniais, que recorriam também ao ver e à sua historicidade? Por outro lado, a ferramenta conceitual das Pathosformeln serve para o tratamento de outras imagens, aquelas chamadas de "técnicas" pela crítica especializada, como o cinema e a fotografia, que, a depender do circuito social, podem, com efetividade, jogar o papel inequívoco de cristalização e veiculação das paixões políticas?

Para finalizar, entendemos, portanto, que o livro de Ginzburg abre clareiras metodológicas que ultrapassam suas referências predominantemente europeias, sendo útil no sentido de pensar, para outras configurações sociais, uma história política, ou uma história social da arte, ou uma história das sensibilidades, que desbordem seus campos tradicionais, pondo em xeque os engavetamentos - "história cultural", "história política" etc. -, e enfocando os problemas a partir do cruzamento de abordagens. 